\title{
Barriers to Career Advancement of Women Chefs Leading to their Poor Visibility in Hotel Industry: A Study with Special Reference to Bengaluru
}

\author{
Usha Dinakaran \\ Department of Hotel Management, Christ (Deemed to be University), Bengaluru, Karnataka, India \\ E-Mail: ushadinakaran@yahoo.com
}

\begin{abstract}
Women chefs are accepted to lead in case of domestic realm of cooking, but the contrast is true in the scenario of professional cooking which is done outside the home boundary, as it is widely viewed as an activity that is executed outside the periphery of women's place. Although many women enrol into culinary schools, they normally do not make it to the frontier because the organizational environment in the culinary sector does not allow them to grow owing to various challenges faced by them. In the present study, a survey $(\mathrm{N}=123)$ among women chefs working in the Hotel industry of Bengaluru, India is conducted to determine the barriers to career advancement of women chefs in the hotel industry of Bengaluru. Barriers to career advancement are due to several reasons like discouragement of upward movement in hierarchy, whole self-authenticity, marginalizing, being less ambitious due to their marital status and lastly lack of confidence which are found to contribute significantly to the opportunities for women chefs in climbing the professional ladder. Following the research study findings, recommendations related to improving the career prospects of women chefs within the hotel industry is put forward.
\end{abstract}

Keywords: Chef, Women Chef, Hotel, Hotel Industry, Culinary

\section{INTRODUCTION}

Cooking is one arena where women have been included and culturally they are expected to cook across the globe. However the expectations of this dominance of women to be reflected in a professional restaurant kitchen as well, is sadly unrealistic. Though with the years of experience and skills in the traditional kitchen, women should do wonders in the professional field, their numbers suggest otherwise, with only $10 \%$ of the executive chefs across the globe being women. As can be noted by different research scholars, the professional kitchens, since a long time, have been male dominated. The insignificant presence of women chefs can be traced back to the fourteenth and fifteenth century when during the war time, the Army was expected to cook [1]. Even with the increase in a number of women culinary graduates, the men still outnumber women chefs by a huge percentage. Women still have not been able to represent themselves in higher kitchen positions within the hotel industry. There are many possible explanations to the limited presence of the women chefs. Among the common perceptions highlighted in the research, women still have to work to be accepted by the "men" working in the kitchen and become one among them. Being one of them entails accepting that the women are accepting to work in an informal work structure which men generally follow [2].

\section{REVIEW OF LITERATURE}

Since women are not considered as being fit to be Chef, and work in the competitive kitchen, it has become a fact that women has chosen to have different lifestyles in terms of becoming a mother, and adjusting to the communal lives in the kitchen [3]. It has become an unspoken tradition in the corporate sector that few women will be able to successfully move up the hierarchical ladder. As a result, these few successful women are who are to rise to the top levels of the culinary sector are indicated by the society as 'exceptions'. This categorization of successful female employees as talented tends to push them out of the male dominated culinary industry. Hence, females exhibiting exceptional culinary skills are thus considered as odd and unconventional. Eventually, their entry in the culinary sector as established chefs are often denied. Women chefs in modern days have recognized their equal value as that of male chefs. But since they remain isolated from the media, from culinary institutions, and from their male peers, they do not have the influence, numbers, or respect to change the reality of restaurant kitchens [4]. Such challenges have led to relegation of women chefs in contemporary world of culinary skills. Gender issues within the hospitality industry, especially for chefs are not the only reason for the nonpopularity of women chefs. Resistance made by men on the entry of women in male dominated industry can be analysed from a different angle. In many cases, men do not discourage their women colleagues at their work. Rather, it can be considered as their preventive measure to resist the negative impacts of female penetration in male dominated occupations that the women workers might face [5]. However, one of the ways by virtue of which this fear among males about the adverse situation that women might face in male dominated works can be prevented is by virtue of making women as efficient and as technically sound as males in the same profession [3]. While studying the relationship of gender issues with different aspects like race, ethnicity and class within the work environment, a number of studies are evaluated, which reflected on the reduced presence of women chefs, more specifically in top positions. Professional kitchen is being dominated by male since military history in the fourteenth and fifteenth centuries and kitchen was male dominated until second half of the twentieth century. After that woman chefs began making their name in small restaurant kitchens though they were unable to establish themselves in the main hotel restaurant kitchens. She also claims that more women were 
increasingly entering and graduating from culinary schools and of course they now represent about $10 \%$ enrolment in culinary schools. She sadly quotes that still women chefs are not accepted in higher positions in many hotel kitchens. She raised questions about life of men and women which is not satisfactory in the present days but claims that in the next 100 years women would take part in all the activities and accomplishments that were once denied to them and also they would never be considered as a protected sex. She also narrates about women in dominance in the home kitchen which would be reflected in the professional restaurant kitchens and she is worried about the negligible $10 \%$ of women executive chefs in US hotel industry [6].

Women are not confident in emphasizing their assertive and authoritative voice at their workplace but they tend to be low and humble about their accomplishments and their knowledge and they talk aggressively only when it affect others as articulated by [7]. Being a woman, she needs to be caring, loving, understanding, soft spoken, patient, accommodative, passionate and so on, creating a 'good girl', image. They want to be noticed and not to be too overambitious either. Women tend to be very emotional than being self-confident, tend to be apologetic than to be decisive, get easily angry when one needs to be quite and become negative than to be positive. Many men in the hospitality industry prefer elderly men to be executives than women, where the discrimination begins [8]. In their research of narratives of female working in the hotel industry, [9] determined the interdependencies of all the factors at play in such an environment. It was primarily found that gender issues, were at interplay with the other factors, thereby creating identities at work that changes with the changing context. Specifically, the researchers found that the lack of power of the female employees as a result of their gender was the most significant reason for the male chefs to harass them in the kitchen.

An unique study to determine the origins of gender issues within the culinary world was conducted by [10] studying its presence/absence in the culinary education and training stage of the chefs within the culinary institutes' culture. More specifically, the researchers attempted to determine the relationship between gender issues and the perceived barriers to the careers. Comparing the perceptions between female and male culinary students, the study revealed that both the gender perceived their barriers to their careers differently, while females were found to be more sensitive to the issue of gender bias than their male counterparts. Furthermore, male culinary students were found to explore their culinary career options to a much lesser extent than the female students who have to make lot of efforts to be able to reach the pinnacle in their career.

\section{RESEARCH METHODOLOGY}

\section{A. Objective of the Study}

To recognize the barriers towards career advancement of women chefs in the hotel industry.

\section{B. Hypothesis}

Multiple barriers towards career advancement of women chefs in the hotel industry has helped develop the following hypothesis to be tested further in the present research study:-

1. Null Hypothesis $\left(H_{N I}\right)$ : Barriers to Career Advancement of women chefs do not contribute towards their limited presence in the hotel industry.

2. Alternative Hypothesis $\left(H_{A 1}\right)$ : Barriers to Career Advancement of women chefs contribute towards their limited presence in the hotel industry.

\section{Design of the Study}

The design of this study is descriptive. The present study employed quantitative research approach, wherein perception and experience of women chefs besides their problems in professional life were obtained. The study was carried out on 123 women chefs working in star hotels in Bengaluru, Karnataka. Purposive sampling method was adopted.

\section{RESULTS AND DISCUSSION}

TABLE I PERCEPTIONS OF AGE AND MARITAL STATUS GROUPS ON CAREER ADVANCEMENT

\begin{tabular}{|c|l|c|c|c|}
\hline Age & Marital Status & N & Mean & SD \\
\hline \multirow{4}{*}{ 21-30 Years } & Single & 14 & 2.6476 & 1.17972 \\
\cline { 2 - 5 } & Married & 26 & 2.4846 & 1.14675 \\
\cline { 2 - 5 } & Others & 5 & 1.7467 & 0.88119 \\
\cline { 2 - 5 } & Total & 45 & 2.4533 & 1.14014 \\
\hline \multirow{4}{*}{ 31-40 Years } & Single & 20 & 2.1367 & 0.95965 \\
\cline { 2 - 5 } & Married & 30 & 2.4556 & 0.92460 \\
\cline { 2 - 5 } & Others & 2 & 2.5333 & 2.07418 \\
\cline { 2 - 5 } & Total & 52 & 2.3359 & 0.96906 \\
\hline \multirow{5}{*}{ 41-50 Years } & Single & 7 & 2.2952 & 0.83343 \\
\cline { 2 - 5 } & Married & 5 & 2.6400 & 1.43573 \\
\cline { 2 - 5 } & Others & 2 & 2.0333 & 1.36707 \\
\cline { 2 - 5 } & Total & 14 & 2.3810 & 1.07096 \\
\hline \multirow{5}{*}{ T1-60 Years } & Single & 3 & 1.8444 & 0.98958 \\
\cline { 2 - 5 } & Married & 5 & 2.5600 & 0.89269 \\
\cline { 2 - 5 } & Others & 4 & 2.2167 & 0.71880 \\
\cline { 2 - 5 } & Total & 12 & 2.2667 & 0.83509 \\
\hline \multirow{5}{*}{ Total } & Single & 44 & 2.3045 & 1.01802 \\
\cline { 2 - 5 } & Married & 66 & 2.4889 & 1.03235 \\
\cline { 2 - 5 } & Others & 13 & 2.0564 & 0.99735 \\
\cline { 2 - 5 } & Total & 123 & 2.3772 & 1.02496 \\
\hline & & & \\
\hline
\end{tabular}

\section{A. Effect of Organisational and Personal Impediments on Women Chefs}

The total aggregate score of the respondents for all the eight variables under organisational impediments is 3670 against 
a maximum score of 4920 indicating agreement of the respondents that organisational impediments act as barriers to career advancement. The researchers [11] similarly detected those organizational impediments such as nonrecognition of women at the workplace being an obstacle the woman face in their career path. Total aggregate score of the respondents for all the seven variables under personal impediments is 3048 against a maximum score of 4305 . The respondents agree that personal impediments act as barriers to career advancement. [12] found that personal life of women, act as a hindrance to their work life, especially their timings and job responsibility, come in their path of a happy family life which is similar to the responses of the women chefs in this research. The total actual score of barriers to career advancement is $6718(3670+3048)$ which is close to the total agreed score of $7380(4 \times 15 \times 123)$ indicate the women chefs agree that barriers to career advancement impinges their growth in hotel industry.

\section{B. Perceptions of Different Groups towards Barriers to Career Advancement of Women Chefs}

The researcher desires to understand the perception of the two groups, age (four levels) and marital status (three levels) considered as independent variables and the scores of barriers to career advancement of women chefs, the dependent variable for the descriptive statistics to understand the perception of different groups of chefs towards career advancement of women chefs.

In the above Table I, the scoring value of chefs belonging to all the four generations ranges from 2.30 to 2.45 indicating comparatively low satisfaction as the values are slightly over 2. This necessitates verification with the help of statistical analysis in the following table.

TABLE II RESULTS OF 4*3 FACTORIAL ANOVA ON BARRIERS TO CAREER ADVANCEMENT

\begin{tabular}{|l|c|c|c|c|c|}
\hline \multicolumn{1}{|c|}{ Source } & $\begin{array}{c}\text { Type III } \\
\text { Sum of Squares }\end{array}$ & Df & Mean Square & F value & P Value \\
\hline Corrected Model & $6.452^{\mathrm{a}}$ & 11 & 0.587 & 0.535 & 0.876 \\
\hline Intercept & 302.228 & 1 & 302.228 & 275.621 & .000 \\
\hline Age & 0.193 & 3 & 0.064 & 0.059 & 0.981 \\
\hline Marital status & 2.056 & 2 & 1.028 & 0.937 & 0.395 \\
\hline Age* Marital status & 3.571 & 6 & 0.595 & 0.543 & 0.775 \\
\hline Error & 121.715 & 111 & 1.097 & & \\
\hline Total & 823.271 & 123 & & & \\
\hline Corrected Total & 128.167 & 122 & \multicolumn{5}{c|}{} \\
\hline \multicolumn{7}{|c|}{ a. R Squared $=0.050$, (Adjusted R Squared = 0.044) }
\end{tabular}

The results in Table II indicate that the four groups included in the variable age, accept the null hypothesis $(\mathrm{f}=.059, \mathrm{df}=3$, p>.05) meaning that among the four groups there is no difference in their perception stating that they are all neither happy nor unhappy. The variable marital status is grouped into three, namely single, married and others. We need to ascertain their perception towards career advancement.

Similar to the case of the age factor, the variable marital status also accepts the null hypothesis stating that their perceptions are same $(\mathrm{f}=0.937, \mathrm{df}=2, \mathrm{p}<0.05)$ among the different groups. These marital status groups also feel that they are neither satisfied nor unsatisfied. Since both age and marital status are accepting the null hypothesis, the interaction effect does not provide any different result and it also accepts the null hypothesis $(\mathrm{F}=0.543, \mathrm{df}=6, \mathrm{p}<0.5)$.

In the Table III the Levene's test is not significant with a $\mathrm{p}$ value of $28.8 \%$. This indicates that all the groups are having equal variant. It is one of the assumptions, if met, Factorial ANOVA is accepted.

\section{TABLE III LEVENE'S TEST FOR BARRIERS TO CAREER ADVANCEMENT}

\begin{tabular}{|c|c|c|c|}
\hline F & df1 & df2 & Sig \\
\hline 0.930 & 11 & 111 & 0.514 \\
\hline
\end{tabular}

C. Rotated Component Matrix for Barriers to Career Advancement

From the rotated component matrix shown in Table IV, high loading factors are identified. The first loading factor consists of eight variable correlated among themselves. All these variables are connected with organizational attitude and hence the first component latent variable is named as organizational impediments.

This variable explained by $81.8 \%$. The second set of components is connected with personal characteristics of women chefs. Combined together this latent variable is named as personal impediments. The variables explained by $6.9 \%$. 
TABLE IV ROTATED COMPONENT MATRIX FOR BARRIERS TO CAREER ADVANCEMENT

\begin{tabular}{|c|c|c|c|}
\hline 常 & Variables & 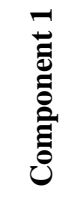 & 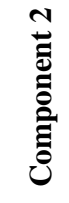 \\
\hline \multicolumn{4}{|c|}{ Organizational Impediments (Component 1) } \\
\hline V 53 & Female employees at managerial level are more harassed & & .853 \\
\hline V 46 & Lack of opportunities for critical work experience and responsibility & & .851 \\
\hline V 47 & Preference to men for higher positions & & .837 \\
\hline V 49 & Structural impediments in career progression & & .828 \\
\hline V 52 & Personal accountability needs to be expanded & & .828 \\
\hline V 51 & Marginalizing of women & & .810 \\
\hline V 48 & $\begin{array}{l}\text { Contributions of women may be recognized but their upward movement in hierarchy is not } \\
\text { encouraged }\end{array}$ & & .714 \\
\hline V 50 & $\begin{array}{l}\text { The whole self-authenticity is a must-have for any women, yet impossible still in many } \\
\text { hotels }\end{array}$ & & .609 \\
\hline \multicolumn{4}{|c|}{ Personal Impediments (Component 2) } \\
\hline V 54 & Women Chefs lack desire and willpower to be at the top & .869 & \\
\hline V 58 & Women chefs underestimate themselves & .867 & \\
\hline V 55 & Life, family and work priorities clash fiercely & .864 & \\
\hline V 56 & Extreme work demands can drain women out & .861 & \\
\hline V 59 & Instinct to be docile and be a helpmate in the kitchen rather than to direct or lead & .854 & \\
\hline V 60 & $\begin{array}{l}\text { Lack of confidence though dedicated, performance conscientious and work without } \\
\text { supervision }\end{array}$ & .840 & \\
\hline V 57 & Women chefs are less ambitious due to their marital status status/commitments & .843 & \\
\hline
\end{tabular}

\section{Fitness of Model for Barriers to Career Advancement}

After observing very good loading and explanation of variables by more than the standard in rotated components matrices, the individual construct reliability is checked.

\section{TABLE V RELIABILITY TEST RESULTS OF ORGANISATIONAL} AND PERSONAL IMPEDIMENTS

\begin{tabular}{|c|c|c|c|}
\hline \multicolumn{2}{|c|}{$\begin{array}{c}\text { Factors of } \\
\text { Organisational } \\
\text { Impediments }\end{array}$} & \multicolumn{2}{c|}{ Personal Impediments } \\
\hline $\begin{array}{c}\text { Cronbach's } \\
\text { Alpha }\end{array}$ & N of Items & $\begin{array}{c}\text { Cronbach's } \\
\text { Alpha }\end{array}$ & N of Items \\
\hline .970 & 8 & .991 & 7 \\
\hline
\end{tabular}

The first set component factors of organisational impediments have eight variables and second set of components have seven variables as seen in Table $\mathrm{V}$ and all the variables of both the components are tested with reliability test. The first set of components indicates Cronbach's .970 which is encouraging as Cronbach's reliability beyond .7 is considered to be good. The second set components of personal impediments when tested for reliability shows Cronbach's .991 which is also highly acceptable.

\section{E. Impact of Career Advancement on the Presence of Women Chefs}

Table VI represents the regression results of barriers to career advancement of women chefs with respect to (1) contributions of women may be recognized but their upward movement in hierarchy is not encouraged, (2) marginalizing of women chefs, (3) less ambitious due to their marital status and lastly (4) lack of confidence though dedicated, performance conscientious and work without supervision. Based on the above table, the F value 840.067 and $p<0.05$ indicate that there is relationship between dependent variable and the predictor variables. Since the probability of $\mathrm{F}$ statistics is $\leq$ the level of significance (0.05), the null hypothesis that there is no linear relationship between the independent and dependent variables is rejected. The alternate hypothesis that there is relationship between the variables is supported.

Given the significance of $\mathrm{F}$ test result, $\mathrm{R}$ square can be interpreted. The table VI shows the $\mathrm{R}$ square value as .973 which indicates all the four independent variables together explained the outcome variable barriers to career advancement of women chefs by $97.3 \%$. The unexplained variable is $2.7 \%$ only. The Durbin Watson is 2.247 though slightly above 2 can be accepted and it shows the fitness of the model. 
TABLE VI REGRESSION RESULTS OF BARRIERS TO CAREER ADVANCEMENT

\begin{tabular}{|c|c|c|c|c|c|c|c|c|}
\hline \multirow{2}{*}{\multicolumn{2}{|c|}{ Model }} & \multicolumn{2}{|c|}{ Unstandardized Coefficients } & \multirow{2}{*}{$\begin{array}{c}\text { Standardized Coefficients } \\
\text { Beta } \\
\end{array}$} & \multirow[t]{2}{*}{$\mathbf{t}$} & \multirow{2}{*}{ Sig } & \multicolumn{2}{|c|}{ Collinearity Statistics } \\
\hline & & \multirow{2}{*}{\begin{tabular}{|c|}
$\boldsymbol{B}$ \\
-0.015 \\
\end{tabular}} & \multirow{2}{*}{$\begin{array}{c}\text { Standard Error } \\
0.040\end{array}$} & & & & Tolerance & VIF \\
\hline 1 & Constant & & & & -0.372 & 0.710 & & \\
\hline & V 48 & 0.172 & 0.031 & .187 & 5.581 & .000 & 0.206 & 4.844 \\
\hline & V 51 & 0.228 & 0.022 & .252 & 10.447 & .000 & 0.397 & 2.517 \\
\hline & V 57 & 0.280 & 0.030 & .313 & 9.336 & .000 & 0.206 & 4.856 \\
\hline & V 60 & 0.289 & 0.033 & .317 & 8.819 & .000 & 0.179 & 5.574 \\
\hline & \multicolumn{2}{|l|}{ F Value } & \multicolumn{6}{|c|}{840.067} \\
\hline & \multicolumn{2}{|l|}{ Sig } & \multicolumn{6}{|c|}{0.000} \\
\hline & \multicolumn{2}{|l|}{$\mathrm{R}$} & \multicolumn{6}{|c|}{$.986^{2}$} \\
\hline & \multicolumn{2}{|l|}{ R Square } & \multicolumn{6}{|c|}{.973} \\
\hline & \multicolumn{2}{|c|}{ Adjusted R Square } & \multicolumn{6}{|c|}{.972} \\
\hline & \multicolumn{2}{|c|}{ Durban Watson } & \multicolumn{6}{|c|}{2.247} \\
\hline & \multicolumn{2}{|c|}{ Predictors (Constant) } & \multicolumn{6}{|c|}{ Variables $50,51,57,60$} \\
\hline & \multicolumn{2}{|c|}{ Dependent Variable } & \multicolumn{6}{|c|}{ Career Advancement (D4) } \\
\hline
\end{tabular}

The variance inflation factor (vif) of all four independent variables is less than 10 , indicating that the independent variables are not highly correlated with themselves. All the four variables included in the analysis against the outcome variable, are significant at $1 \%$ significant level with positive relationship. Even one unit of increase of the independent variables, (1) Contributions of women may be recognized but their upward movement in hierarchy is not encouraged, (2) marginalizing of women chefs, (3) less ambitious due to their marital status and lastly (4) lack of confidence though dedicated, performance conscientious and work without supervision, the dependent variable increases by 0.172 , $0.038,0.228,0.280$ and 0.289 respectively. The study shows that all the four independent variables are positively affecting the dependent variable, barriers to career advancement.

This suggests that social and cultural perceptions against women chefs, arising from general gender stereotyping issues were the main contributors of towards barriers to career advancement and lack of women chefs at the top positions in the hotel industry. [13] also stated that women lacking the desire to be at the top of the hierarchy provide an advantage to their male counterparts to grab the opportunity for themselves. There exists a perpetual confidence gap, the gap between how little women think of themselves compared to how highly men do. On many occasions women chefs tend to underestimate themselves by overestimating the risks.[14] Margie Warrell (2016) stated that "A lack of belief in our own value, worth \& ability tempers female ambition \& holds women back".

\section{FINDINGS}

Organizational impediments indicate that $40.4 \%$ of the women chefs agree and $27 \%$ of them strongly agree that it acts as barriers to career advancement of women chefs.
Among the different organizational impediments, lack of opportunities for critical work experience and responsibility $(43.9 \%)$, marginalizing of women $(43.9 \%)$, structural impediments preventing women chefs from progressing to higher positions (42.3\%) and preference to men for challenging and responsible positions at the top (41.5\%) were among the most popular reasons acting as barriers to career advancement of women chefs.

Considering personal impediments, $35.5 \%$ of the women chefs agree and $21.7 \%$ of them strongly agree that personal impediments have a role to play in their career advancement. Clash of life, family and work priorities (37.4\%), feeling of women chefs that they should be docile and be a helpmate in the kitchen rather than being a leader (36.6\%) and lack of confidence, though women chefs are dedicated, conscientious in their performance and need less supervision $(36.6 \%)$ were the top three factors of personal impediments which stalled the career path of women chefs. Overall the women chefs agree that personal impediments act as barriers to career advancement. The women chefs do agree that barriers significantly influence their career advancement.

Among the different organizational impediments, (1) lack of opportunities for critical work experience and responsibility, (2) marginalizing of women, (3) structural obstacles preventing women chefs from progressing to higher positions and (4) preference to men for challenging and responsible positions at the top were among the most popular reasons acting as barriers to career advancement of women chefs. In terms of personal impediments (1) clash of life, family and work priorities, (2) feeling of women chefs that they should be docile and be a helpmate in the kitchen rather than being a leader, (3) lack of confidence in women chefs despite being dedicated, conscientious in their performance and need less supervision were the major three 
factors of personal impediments which stalled the career path of women chefs.

The perceptions of women chefs from all the four age and three marital groups are same and found to have no significant relationship with career advancement. The impact of four variables, (1) contributions of women chefs may be recognized but their upward movement in hierarchy is not encouraged, (2) marginalizing of women chefs, (3) being less ambitious due to their marital status and lastly (4) their lack of confidence though they are dedicated, performance conscientious and work without supervision contribute the most towards the barriers to career advancement of women chefs. The two variables, (1) lack of confidence of women chefs though they are dedicated, performance conscientious and work without supervision and (2) being less ambitious due to their marital status are the barriers having a greater influence which stalled the career path of women chefs leading to their limited presence in the hotel industry.

\section{RECOMMENDATIONS}

Gender equality needs further deliberation. Provision and implementation of gender sensitizing training and workshops are required within the hotel industry, involving unofficial and official methods of encouraging gender equality treatment at workplace. Participation of husbands in sharing family responsibilities like attending the academic requirements of children will help the women in reducing their family pressure. Hence the social change or even discussion towards this change should take place in every home to aid the women chefs in their career advancement. With increasing social media pressure for establishing gender equal workplaces, the management of hotel industry should focus on introducing changes in their company policies and even make efforts to change the work culture and environment. Necessary policies should exist and implemented to provide equal opportunities for the women chefs in proceeding up the professional ladder in the hotel industry.

\section{CONCLUSION}

Conclusions can be drawn from the findings of both primary and secondary data analysis. Among the reasons which were identified in the research about limited presence of women chefs in top positions, stereotyping was found to impact women in the industry. Common perceptions shared within the primary and secondary data include that; women chefs cannot handle 'hot kitchens' and long hours and also mental and psychological lacking in women chefs themselves for not being suitable for leadership roles. This failure is because of lack of gender related mechanisms put into place, besides failing to successfully mobilize counter-views in the public regarding the power processes persisting within the society and hence the industry for creating empathy towards women chefs [15].

\section{REFERENCES}

[1] Cooper, Ann. (1998). A Woman's Place is in the Kitchen: An Evolution of Women Chefs. New York: Van Nostrand Reinhold.

[2] Fine, G. A. (1987). One of the Boys: Women in Male-Dominated Settings. In Changing Men: New Directions in Research on Men and Masculinity, ed. Michael S. Kimmel. Newbury Park: Sage Publications, 131-45.

[3] Druckman, C. (2010). Why Are There No Great Women Chefs? Gastronomica, 10(1), 24-[4].

[4] Sutton, Ryan. (2014). Women Everywhere in Food Empires But No Head Chefs. Bloomberg.

[5] Harris, D. A., \& Giuffre, P. (2015). Taking the heat: women chefs and gender inequality in the professional kitchen. New Brunswick, NJ: Rutgers University Press.

[6] Woolf, V. (1929). A Room of One's Own (1989 ed.). London: A Harvest Book, Harcourt Inc.

[7] Ouston, J. (ed.) (1993). Women in Education Management. Harlow: Longman.

[8] Zinyemba, A. (2013). Leadership challenges for Women Managers in the Hospitality and Financial Services in Zimbabwe. International Journal of Advanced Research in Management and Social Sciences, 2(4), 50-57.

[9] Adib, A., \& Guerrier, Y. (2003). The Interlocking of Gender with Nationality, Race, Ethnicity Class: the Narratives of Women in Hotel Work. Gender, Work \& Organization, 10(4), 413-432.

[10] Chuang, Ning-Kuang. (2010). The Impact of Gender on Hospitality Undergraduates Perceived Carrier Barriers. Journal of Hospitality and Tourism Education, 22(3), 12-19.

[11] Whitmarsh, Lona, Yolanda Hawkins-rodgers, and Diane Keyser Wentworth. 2007. Choices and Challenges: A Qualitative Exploration of Professional Women's Career Patterns. The Career Development Quarterly, 55(3), 225-36.

[12] Rehman, Sumaira, and Muhammad Azam Roomi. (2012). Gender and Work-Life Balance: A Phenomenological Study of Women Entrepreneurs in Pakistan. Journal of Small Business and Enterprise Development, 19(2), 209-28.

[13] Eagly, Alice H. (2007). Female Leadership Advantage and Disadvantage: Resolving the Contradictions. Psychology of Women Quarterly, 31(1), 1-12.

[14] Warrell, M. (2016). For Women To Rise We Must Close 'The Confidence Gap'. Retrieved from https:/www.forbes.com/sites/ Margie warrell/\#3f421ec75eca.

[15] White, Alan. (2011). Developing a Model for Analysing Operational Powers That Lead to Low Participation of Women in Elite Kitchens. Cardiff School of Management, University of Wales Institute. 